\title{
ANTIBODY ANTI-DENGUE PROFILE IN DENGUE HEMORRHAGIC FEVER PATIENTS AT DR. SOETOMO HOSPITAL, SURABAYA
}

\author{
Langgeng A Waskito ${ }^{1}$, Paulus B Notopuro ${ }^{2}$, Pepy Dwi Endraswari ${ }^{3}$ \\ ${ }^{1}$ Medical Doctor Study Program, ${ }^{2}$ Department of Clinical Pathology \\ ${ }^{3}$ Department of Microbiology, Faculty of Medicine, Airlangga University
}

\begin{abstract}
ABSTRAK
Demam berdarah dengue merupakan salah satu penyakit infeksi yang memiliki kasus dengan jumlah kematian tinggi di Indonesia. Penelitian ini bertujuan untuk menggambarkan profil antibodi anti-dengue pada pasien demam berdarah dengue di RSUD Dr. Soetomo Surabaya. Penelitian ini memberikan gambaran secara epidemiologis untuk mengetahui prevalensi infeksi primer dan infeksi sekunder dari demam berdarah dengue dan gambaran klinisnya. Penelitian ini menggunakan 85 sampel dengan mengambil data rekam medis dari uji serologis anti-dengue IgM dan IgG dari Instalasi Penyakit Dalam RSUD Dr. Soetomo Surabaya antara Januari hingga Desember 2010. Data dikumpulkan dan dianalisis dalam diagram dan tabel. Hasil dari penelitian ini adalah 25 $(29,4 \%)$ pasien dengan uji serologis IgM positif, 14 (16,4\%) pasien dengan uji serologi IgG positif dan 46 (54,2\%) pasien dengan uji

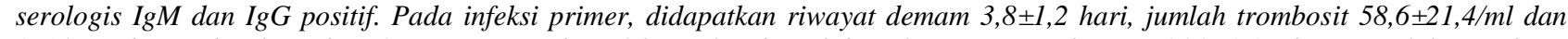
$37 \%$ tanda perdarahan dari 25 pasien. Pada infeksi sekunder, didapatkan riwayat demam 4,28 $\pm 1,15$ hari, jumlah trombosit 44,17+24,2/ml dan 52\% tanda perdarahan dari 60 pasien. Kesimpulan menunjukkan bahwa pasien dengan infeksi sekunder memiliki prevalensi lebih tinggi dari infeksi primer. Selain itu infeksi sekunder memiliki gambaran klinis yang lebih berat dari infeksi primer. (FMI 2015;51:173-176)
\end{abstract}

Kata Kunci: demam berdarah dengue, antibodi, anti-dengue

\begin{abstract}
Dengue hemorrhagic fever is one infectious diseases that have high case fatality rate in Indonesia. The aim of this study was to descibe the antibody anti-dengue profile in dengue hemorrhagic fever patients at Dr. Soetomo Hospital Surabaya. This study was epidemiological descriptive study to aims prevalence primary and secondary infection of dengue hemorrhagic fever and its clinical appearances. This study used 85 samples by taking medical record data of IgM and IgG anti-dengue serologic test from Internal Medicine Department, Dr. Soetomo Hospital, Surabaya, between January to December 2010. The data were collected and analyzed in diagrams and tables. Result of this study showed 25 (29,4\%) patients had positive IgM serologic test, 14 (16,4\%) patients had positive IgG serologic test and 46 (54,2\%) patients had positive IgM and IgG serologic test. In primary infections, the history of fever was $3.8 \pm 1.2$ days; platelet counts $58,6 \pm 21,4 / \mathrm{ml}$ and bleeding sign $37 \%$ of 25 patients. In secondary infections, the history of fever was $4.28 \pm 1.15$ days; platelet count was $44,17 \pm 24,2 / \mathrm{ml}$ and bleeding sign $52 \%$ of 60 patients. In conclusion, patients with secondary infection have higher prevalence than primary infection. Then in secondary infection had more severe clinical appearance than primary infection. (FMI 2015;51:173-176)
\end{abstract}

Keywords: dengue hemorrhagic fever, antibody, anti-dengue

Correspondence: Langgeng A Waskito, Medical Doctor Program, Faculty of Medicine, Airlangga University, Jl. Prof dr. Moestopo 47, Surabaya 60131, Indonesia.

\section{INTRODUCTION}

Dengue fever (DF) and dengue hemorrhagic fever (DHF) are infectious diseases caused by dengue virus with clinical manifestations of fever, muscle and joint pain that is accompanied with leukopenia, rash, lymphadenopathy, thrombocytopenia and hemorrhagic diathesis. Plasma leakage in DHF is characterized by hemoconcentration (increased hematocrit) or accumulation of fluid in the body cavity. Dengue shock syndrome is dengue hemorrhagic fever which characterized by shock (Suhendro, Nainggolan, Chen 2006). Dengue hemorrhagic fever was first identified in 1950s in Thailand and Philippines. In Southeast Asia, DHF becomes major cause of hospitalization and death in children. Approximately 1.8 billion (over $70 \%$ ) population of the world are at risk of suffering from dengue fever, especially in the Southeast Asia and the Western Pacific region (WHO 2009).

In Indonesia, 150,000 cases were reported in 2007 (highest record in Indonesia) with the highest cases occurred in Jakarta and West Java, with fatality rate reaches $1 \%$ (WHO 2009). According to the Health Department, from January until March 5, 2004, the total dengue cases in all provinces in Indonesia has reached 
26015 , with as many as 389 deaths $(\mathrm{CFR}=1.53 \%)$. The highest case was reported in DKI Jakarta (11.534 people) while the CFR was highest in NTT Province (3.96\%) (MOH 2004). In the period 2001 to 2007, there were a total of $4,332,731$ cases of dengue in over 30 countries in Americas. The number of dengue cases in the same period was 106 037, with the death toll reached 1,299 people, while the rate case fatality rate reached 1.2\% (PAHO 2008).

IgM antibodies first appeared in immunoglobulin isotope. These antibodies were detected in $50 \%$ of patients within 3-5 days when disease symptoms begin to appear, and then increased up to $80 \%$ on day 5 and $99 \%$ on day 10 . Serum anti-dengue $\mathrm{IgG}$ is generally detected at low titers at the end of the first week of disease, then increased slowly, and serum $\operatorname{IgG}$ was detected after a few months, even forever. During secondary infection, where the infection has been previously infected with dengue virus or dengue virus non-vaccine, IgG antibodies were detected at a high level. The early stages of healing IgM levels were lower in the secondary infection significantly rather than primary infection. To distinguish primary and secondary infection, IgM and IgG results are now used more frequently than the haemagglutination-inhibition (HI) test (WHO 2009). By using the WHO standards, IgM and IgG profiles were studied to identify prevalence of patients with primary and secondary infection of dengue fever in the Department of Internal Medicine, Dr. Soetomo Hospital, Surabaya.

\section{MATERIALS AND METHODS}

This was a descriptive observational study aimed to reveal serum IgM and $\operatorname{IgG}$ profiles in patients with dengue fever by using secondary data. Data were obtained from Medical Health Document of the patients in the form of name, gender, date of hospitalization, physical examination data, laboratory examination data, including the results of serum IgM and IgG antibodies at the Department of Internal Medicine, Dr. Sutomo Hospital, Surabaya, from January 1, 2010 to December $31,2010$.

Samples were taken by simple random sampling from the population that fulfilled the inclusion criteria, ie patients who have been treated for at least 5 days after the symptoms of dengue fever, patient who has performed serological antibody anti-dengue $\operatorname{IgM}$ and IgG, patients had complete DMK (Medical Documents health). Then the data was collected and categorized based on the results of serum IgM and IgG antibodies.

\section{RESULTS}

From January 2010 to December 2010 the number of patients registered as dengue hemorrhagic fever patients at the Department of Internal Medicine, Dr. Soetomo Hospital, was as many as 1613 patients. The samples were 85 patients based on inclusion and exclusion criteria, out of 102 patients taken during the study investigators. The results of this study found that among 85 samples taken, $25(29,4 \%)$ patients with positive IgM serologic test; $14(16,4 \%)$ patients with positive IgG serologic test and $46(54,2 \%)$ patients with positive IgM and $\mathrm{IgG}$ serologic test.

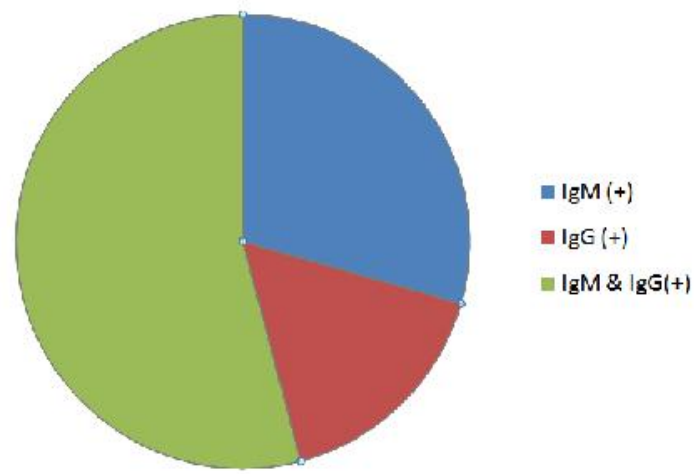

Figure 1. The results of serological anti-dengue

Primary infection of dengue hemorrhagic fever cases illustrated by the results of serological IgM anti-dengue positive. As for secondary infections illustrated by the results of serological IgG anti-dengue positive or $\operatorname{IgM}$ and IgG anti-dengue positive. From the results of classification of primary and secondary infection, for patients with primary infection acquired overview history of fever $3.8 \pm 1.2$ days and the results of the platelet count of $58.6 \pm 21.4 / \mathrm{mL}$. As for patients with secondary infections acquired overview history of fever $4: 28 \pm 1: 15$ and examination results in platelet count of $24.2 \pm 44.17 / \mathrm{mL}$.

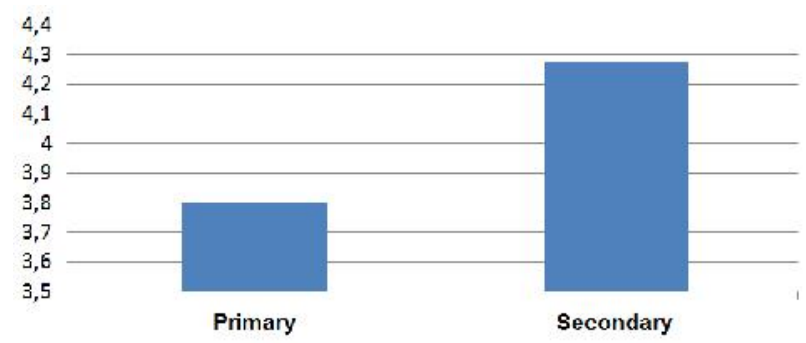

Figure 2. History of fever patients with primary infection and secondary infection 


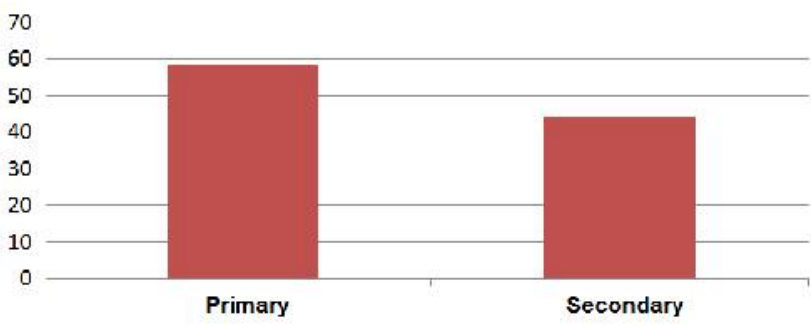

Figure 3. Examination results of patients with platelet count of primary infection and secondary infection

Profile of bleeding symptoms showed that of 25 patients with primary infection, those with bleeding symptoms were $37 \%$ and the remaining $63 \%$ had no such symptoms. Meanwhile, of 60 patients with secondary infection, those with bleeding symptoms were $52 \%$ and the remainding $48 \%$ had no bleeding symptoms. Symptoms included spontaneous bleeding, eg bleeding gums, nosebleeds, dysentery or positive rumple leed test results.

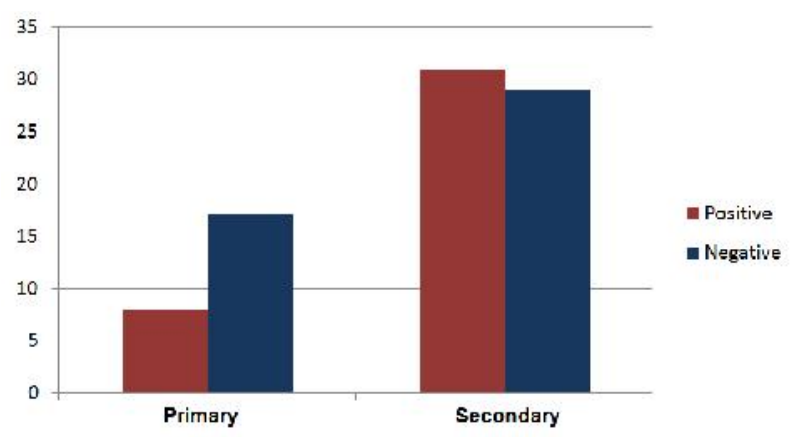

Figure 4. Bleeding symptoms by a primary infection and secondary infection

\section{DISCUSSION}

This study was descriptive epidemiological study that describes the profile of anti-dengue antibodies in patients with dengue hemorrhagic fever. The variables examined included history of fever, signs of bleeding, platelet count and serological results of $\operatorname{IgM}$ and $\mathrm{IgG}$ anti-dengue, in patients is treated in Dr. Soetomo Hospital in the periode of January 2010 to December 2010.

The results of this study found that among 85 samples taken, $25(29,4 \%)$ patients with positive IgM serologic test; $14(16,4 \%)$ patients with positive IgG serologic test and $46(54,2 \%)$ patients with positive $\operatorname{IgM}$ and $\operatorname{IgG}$ serologic test. Thus, of the 85 patients as many as $70.6 \%$ had secondary infection and $29.4 \%$ were exposed to primary infection. This suggests that the majority of patients who came to Dr. Soetomo Hospital had previously suffered from dengue fever. IgM antibodies were detected in $50 \%$ of the patients with dengue infection 3-5 days when symptoms began to appear, and then increased up to $80 \%$ on day 5 and $99 \%$ on day 10 (PAHO 2007). In the primary dengue infection, which was the first infection, the antigen-activated B cells was still inactive. With B-cell activation, clonal expansion occurred in human immune process (Abbas \& Lithcman 2007). After clonal expansion, there were three further mechanisms, i.e. the release of IgM antibodies, the formation of B-cells expressing IgG antibodies IgG and subsequently the release of B-cells formation, which then formed a great affinity of memory B cells. IgM antibodies were detected in $50 \%$ of the patients with dengue infection 3-5 days after the symptoms began to appear, and then increased up to $80 \%$ on day 5 and $99 \%$ on day 10 (PAHO 2007). Because IgM formation in this process was faster and serological examination in dengue infection was performed on day 5, so high IgM levels could be used as a positive marker of primary infection with dengue hemorrhagic fever. Basically, anti-dengue serum IgG titers are detected low at the end of the first week of illness, then increases slowly and serum IgG is detected after a few months, and may be even forever. In the patients, the IgG levels were still low. This led to negative test results. Therefore, serological examination of primary dengue virus infection detected only IgM positive. However, in secondary infection IgM levels very low titre is formed, with the outcome that serological tests can only show negative results (Buchy et al. 2006).

The distribution pattern of dengue virus serotypes in Surabaya in 2003-2005 consisted of 52\% DEN-2; $20 \%$ DEN 1; $16 \%$ DEN-3 and DEN-4 12\% (Aryati 2006). This suggests that of the four serotypes circulating in Indonesia are dominated by DEN-2, DEN-1 followed by; DEN-3 and DEN-4. The shift of predominant serotype in Surabaya in 2008-2010 was of DEN-2 DENdominant. In fact, serotype DEN-1 can be divided into DEN-1 and DEN-1 genotype 1 genotype 2 (Yamanaka 2011). This further reinforces the notion that serotype circulating in Surabaya was very diverse and raised the number of secondary infections in patients with dengue hemorrhagic fever in Surabaya.

Based on observations of the patient's clinical features, the results showed that patients with secondary infections had more severe clinical features. This was evidenced by the number of platelets that was averagely of $44.17 \pm 24.2 / \mathrm{mL}$ than in patients with primary infection with an average of $58.6 \pm 21.4 / \mathrm{mL}$. Moreover, in patients with secondary infections were more common symptoms of bleeding was found in $52 \%$ of the 60 patients, rather than patients with primary infection where symptoms of bleeding was found in 
$37 \%$ of 25 patients. Symptoms of bleeding included spontaneous bleeding, such as nosebleeds, bleeding gums and rumple leed test results. Thus the prognosis in patients with secondary infections tend to get worse and needed more intensive treatment. Whereas, based on the observation of fever history in the hospital, patients with primary infection came with averagely 3-4 days of fever. Patients with secondary infection came with averagely 4-5 days of fever.

Patients with primary infection are associated with mild clinical appearance, whereas patients with secondary infections are associated with severe clinical presentation (Widodo 2009). The clinical appearance of the signs includes bleeding that can be followed as well as the results of platelet shock which tends to be lower. Immunological mechanisms underlying this phenomenon was mechanism of cross-reactivity in secondary dengue virus infections. Cross reactivity is a different mechanism in which an antigen is captured and expressed on antibody that has been formed in the body of previous hosts (Porrozi 2004). This leads cross reactivity of the entering antigens have not been neutralized first, So the antigens or viruses enter the Fc receptor-bearing cells, such as monocytes or macrophages. This causes an increase in the number of antigen-presenting cells (APC) that activates precursor cross-reactivity of memory $\mathrm{T}$ cells. This sequence of events leads to the release of chemical mediators that causes plasma leakage and increases severity of the disease (Vaughn 1997). In this study, patients with secondary infections had more severe clinical presentation. This was indicated by the results of a positive manifestation of bleeding and lower platelet examination. Thus, the results of this study was consistent with the literatures (Vaughn 1997).

\section{CONCLUSION}

Examination of serum IgM and IgG revealed that most (70\%) of the patients had secondary infections and $30 \%$ had primary infection. It is due to the presence of dengue virus serotype diversity as well as the shift of the dominant serotype of dengue virus in Surabaya. Clinical features in patients with secondary infections tend to be more severe than that in patients with primary infection. This is indicated by the symptoms of more bleeding and lower platelet count.

\section{REFERENCES}

Darmowandowo, Widodo (2006). Continuing Education Ilmu Kesehatan Anak ke-36, Kapita Selekta Ilmu Kesehatan Anak VI. Surabaya: SMF Ilmu Kesehatan Anak FK Unair-Dr. Soetomo Hospital Surabaya

Porrozzi R, Teva A, Amaral VF, Santos Da Costa MV, Grimaldi Jr G (2004). Cross-immunity experiments between different species or strains of Leishmania in rhesus macaques (Macaca mulatta). The American journal of tropical medicine and hygiene, 71 (3): 297305

PAHO (2008). Number of reported cases of dengue and dengue hemorrhagic fever (DHF), Region of the Americas (by country and subregion). Washington, DC, Pan American Health Organization. Available from:h ttp://www.paho.org/english/ad/dpc/cd/dengue.htm

Soegianto, S (2006). Patogenesa dan Perubahan Patofisiologi Infeksi Virus Dengue. Available from: http://www.pediatrik.com/buletin/20060220-8ma2gibuletin.pdf. Accessed Mei 12, 2011.

Vaughn, David (1997). Dengue in the Early Febrile Phase: Viremia and Antibody Responses. The Journal of Infectious Diseases, 176:322-30

WHO (2009). Dengue Guidelines for Diagnostic, Treatment, Prevention and Control. WHO press, Jeneva

Yamanaka, Atsushi, et al. (2011). Displacement of the Predominant Dengue Virus from Type 2 to Type 1 with a Subsequent Genotype Shift from IV to I in Surabaya, Indonesia 2008-2010. PLoS ONE 6(11): e27322. doi:10.1371/journal.pone.0027322

Aryati, Soetjipto, Hariadhi S, Rantam FA, Soegijanto S. 2006. Profile serotype virus dengue di Indonesia tahun 2003-2005. Maj. Ked. Trop. Ind. (MKTI). 17(1): 72-80. 